\title{
The Concept of Juristocracy on Trial: Reality or Fiction?
}

\author{
Norbert KIS ${ }^{1}$
}

This article aims to investigate the controversial concept of Juristocracy that has been widely analysed recently. This theory claims that lobbyists representing a liberal ideology have formed an oligarchy of lawyers in EU institutions. These juristocratic networks seek to limit the sovereignty of post-liberal, legitimate national governments. The concept extends to other supranational institutions as well as NGOs and academic networks. This study discusses the political ambition of lawyers of EU institutions and their existence as political protagonists i.e. Juristocracy. However, the theory of Juristocracy addresses some historical phenomena. The EU's bureaucracy has become a "power institution" and tends to compete with national governments. In this socio-evolutionary struggle, both legal and political theories can easily become "power theories". The concept of Juristocracy reflects the weakening global influence of neoliberal values as well as the changing role of post-WWII supranational institutions. In this respect, juristocratic networking can be seen as a historical necessity as much as it has to do with the conflict of supranational and national governance, in particular within the EU. The legitimacy and public trust of supranational institutions is more and more challenged, thus the study concludes the need for a new, win-win deal between national governments and supranational institutions. Otherwise, in the long-term, nation states will only survive if relying on historical and sociopsychological foundations.

Keywords: Juristocracy, liberalism, European Union, supranational, nation state, illiberal, political power

University of Public Service, Professor, Vice-Rector for Institutional Development; e-mail: kis.norbert@uninke.hu 


\section{Introduction - The concept of Juristocracy}

Recently, there has been a massive amount of literature devoted to the concept of Juristocracy. ${ }^{2}$ The latest monograph about the juristocratic operation of the European Union was published in 2018. ${ }^{3}$ The author Béla Pokol, judge of the Hungarian Constitutional Court, invented a new approach to European Juristocracy. The essence of it is that lobbyists with a fundamentally liberal worldview form a certain constitutional oligarchy or network of lawyers within EU institutions. Their operational fields include the European Court of Justice (ECJ), the European Court of Human Rights (ECHR), the EU Commission, constitutional courts of European countries, and moreover the international courts, universities and NGOs. Juristocracy enforces its own liberal-oriented political values through jurisprudence, common law, the attitude of legal defence and the created legal language and legal doctrines. With the loss of space of liberal politics, these juristocratic networks seek to limit the leeway of post-liberal, legitimate national governments. Juristocracy tends to limit democratic forces having electoral legitimacy and democracy itself. The EU has become a Juristocracy since the ECJ cannot even be limited by the Member States' common policy. However, the ECJ represents the limitation of the Member States and strengthens EU integration. The oligarchy of lawyers within EU institutions represents a policy of a "federal Europe" in a targeted manner. The examined phenomenon relates to the enforcement of the interests of the elite advocating globalisation; it is about the lawyers' oligarchy operating as part of the global network or a so-called global constitutional oligarchy. Pokol's concept argues for the complexity and coherence of the above phenomena, and illustrates how Juristocracy works, what its motives, aims and ambitions are.

The concept questions the bona fide approaches related to the European Union epistemic communities. ${ }^{4}$ The European Court of Human Rights (ECHR) deals with 40,000-60,000 submissions a year, the European Court of Justice (ECJ) manages between 1,600 and 1,700 cases related to 27 Member States in 24 languages. The EU Commission is the administrative enforcement mechanism of a union of a population of 500 million. Serious professional legal and clerical staff have been managing the European caseload for decades with refined mechanisms and precedents. The question arises whether the above-mentioned forums, which have become the drivers of European integration, have been distorted. Have they gone down the path of exercising political power as institutions

2 Benedict Kingsbury, 'Foreword: Is the Proliferation of International Courts and Tribunals a Systemic Problem?', N. Y. U. Journal of International Law and Politics 31 (1999); Mathilde Cohen, 'Judges or Hostages? Sitting at the Court of Justice of the European Union and the European Court of Human Rights', in EU Law Stories. Contextual and Critical Histories of European Jurisprudence, ed. by Fernanda Nicola and Bill Davies (Washington, D.C.: Cambridge University Press, 2017), 58-80; Ran Hirschl, Towards Juristocracy. The Origins and Consequences of the New Constitutionalism (Boston: Harvard University Press, 2004); Alexander Somek, 'Administration without Sovereignty', in The Twilight of Constitutionalism?, ed. by Petra Dobner and Martin Loughlin (Oxford: Oxford University Press, 2010), 286; Ruti Teitel and Robert Howse, 'Cross-Judging: Tribunalization in a Fragmented but Interconnected Global Order', N. Y. U. Journal of International Law and Politics 41 (2009), 292-294.

3 Béla Pokol, Európai jurisztokrácia [European Juristocracy] (Budapest: Dialóg Campus Kiadó, 2019).

4 Anthony R Zito, 'Epistemic Communities, European Union Governance and the Public Voice', Science and Public Policy 28, no 6 (2001), 465-476. 
committed to the application of law? If so, what factors and objectives have transformed these institutions into lawyer oligarchies and Juristocracy with ambitions for political power?

One of the keywords of the possible answers is "political power". Perhaps it is necessary that, over time, the above-mentioned European institutions have become "power institutions" and the apparatuses a "power arm" driven by their own survivalist "social instinct". According to the theory of cultural evolution, ${ }^{5}$ there is a competition of survival between the social and political groups as well, whether they are nation state or international organisations. At this point, the tragic conflict between Juristocracy and the nations fearing for their sovereignty seems inevitable. By analysing the phenomenon, both legal theory and political theory can easily become a "military theory" or "power theory". In this civil, military theory, every institution and group is actually politicised and does so with ambitions of power. The institutions and their members become power factors and part of the power rivalry. In their assessment, the only thing that remains is the issue of martial belonging and of open or hidden political, i.e. power goals. Legal values are "devalued" to underlying political interests, and legal reasoning becomes political. On the one side in the fight there are nation state forces legitimised by the will of the electorate. On the opposite side there are the "institutions of power" which are not legitimised by the votes of the people. National sovereignty is opposed to the legal apparatus and bureaucracy aiming at the control and limitation thereof. However, the fight is not of legal but political nature. This is where the theory of Juristocracy begins, and which defines the boundaries of a power-sharing conflict between the EU and the nation states.

The concept of Juristocracy is important in understanding the driving forces behind the ongoing changes in this historical and political era of Europe. The ideology of liberal politics is declining, the main ideology of the new era is still immature, and its name is uncertain (e.g. post-liberal, illiberal, postmodern, Christian). One thing is clear: we are entering a post-liberal era. It is also apparent that a multipolar world order is emerging. The global influence of U.S., neoliberal values and interests is also weakening. The contrast between the ideas of the vanishing and the new era is becoming sharper. The concept of Juristocracy reveals the axioms of this new historical ideology. However, the revelative power of the views on Juristocracy mainly lies in making the power struggle visible, i.e. the ambition of institutional groups, networks and power elites that they fight against nation states and their governments. It is not just a matter of debate, disagreements and different ideologies. It is a hard fight, a political "war" in Europe. According to the laws of cultural evolution, the "natural" character of the power struggle between groups has been evolving. It explains why the institutions and apparatuses presented do not always do what they are supposed to do, that is, to enforce and apply the law, but ultimately, they follow their evolutionary nature: they want to attain more (political) power and dominance.

5 Robert Boyd and Peter J Richerson, Culture and the Evolutionary Process (Chicago: University of Chicago Press, 1985); Vilmos Csányi, Az evolúció általános elmélete [The General Theory of Evolution] (Budapest: Akadémiai Kiadó, 1979). 


\section{Challenges of the theory of Juristocracy}

The phenomenon of European Juristocracy itself, is a theory. In case of a theory, it is not necessarily important to examine the justification or refutation of the existence of the phenomenon and of the assertions made. Of course, a theory of scientific value requires systematic verification and justification. However, a theory can exist independent thereof. The ontology of the theory, that is, the cause and meaning of its existence, should be a matter of examination, especially if it appears to be necessary in the post-liberal ideology or even an essential component thereof. A theory provides a new framework for the organisation of thoughts, through which the world and phenomena can gain (new) meaning. The theory, therefore, should not be examined along "true-untrue" or "real-unreal" paradigms, but rather provide a new narrative for facts. The theory is not the mirror of objective reality. European Juristocracy as a theory is an intersubjective reality. ${ }^{6}$ The thoughts of the community accepting the axioms of the theory make it a reality, that is, an intersubjective reality. Those who challenge the theory think of another intersubjective reality that does not see Juristocracy behind the same facts. European Juristocracy as a theory is an element of an increasing intersubjective reality. It exists, it is real, so the big question is why it has been created. Is there a quality of existence or is it a historical necessity? As it may be a historical necessity, is there a demand that the theory should not exist?

The theory of Juristocracy claims that values and progression evolved so far to become a phenomenon that binds nation states and limits democracy. For decades, the international and European judiciary, the harmonisation of European law and human rights protection, have been the symbols of political progression. The commonality of values and interests shared by the nations that upheld the belief in the impartiality of these institutions seems to have become weakened. Impartiality means that these institutions do not politicise, but enforce the law. This is why governments and nations have accepted international and European "judicial supervision" for decades. At this point, the historical conflict model of "above" and "below" is also outlined. The people, democracy and the nation state turn against the institutional authorities that have been raised "above" and grown beyond them. All this reinforces the notion that the interpretation of the institutions and values of politics and law must be considered in the context of the given historical period. This also requires a certain historical timeframe, so changes in the present (current decades) cannot be accurately diagnosed yet. The world entered the $21^{\text {st }}$ century with political institutions based on interests and values that had been created by the traumas of World War I and World War II, and the great powers' deals reacting thereto. The essence of this was to restrain national politics and governments, otherwise they might become a "powder barrel”. There was a need for international institutions to have control over nation states that are basically entrusted with law application. This legitimised the institutions of the UN, international law, international courts, the ECHR, the European Community and later the EU, the EU Commission and the ECJ to date. The Atlantic global political interests of the U.S. were also built on these institutions during the Cold War decades and after 1990. In the 1950s, an important motive for European integration was the economic revitalisation of Europe

Yuval N Harari, Homo Deus (Harper Collins, 2018). 
and the strengthening of industrial and commercial relations as well, but ultimately these were rather tools for avoiding another war. However, in the first decade of the $21^{\text {st }}$ century, the historical motives of the international supranational institutions and those represented by the EU began to weaken. Why? We can identify four coefficients:

1. An important socio-psychological factor is that the nightmare of the two World Wars has faded away due to the passage of time. The half-a-century thesis that national governments were war risks and must be controlled and restrained has been undermined. The wars of the 1990s in the Balkans and the interventions of the Russian War in Ukraine (2014) have also failed to provide new legitimacy to the supranational control system of international and European law and institutions.

2. The U.S. can no longer function as a political global power. A multipolar order of power is emerging. The half-a-century rule of international institutions is disintegrating.

3. The "pyramid scheme" of the global financial system collapsed in 2008. Although the fraudulent system was built in Wall Street, the institutions with global competence have also lost trust and confidence. The financial collapse also proved the unsustainability of the weakened liberal "governance” systems.

4. The EU remained paralysed even during the financial crisis of 2008 and the later wave of ongoing mass migration. European integration has come to a halt when the British left the EU.

To sum up, eight decades after the two World Wars, the war risk factor of nation states is no longer able to provide enough legitimacy for either international or EU institutions. Local/national sovereignty provides the people with a more secure grip on the present and future problems than supranational institutions built on the fears of the past. The thesis of "for fear of nations" worked until nation states faced the experience of "we can only count on ourselves". The global financial crisis (2008) and the intensification of mass migration have awakened the capacity of nations and their governments since they feel the security of their everyday life at risk. An active national policy requires room for manoeuvre as it is answerable to the voters for preventing and handling the problems that jeopardise the future. Voters do not live in the past; they want a solution to the real problems of the present and hold national governments accountable for it. The national political reality is struggling in the present and future, but the perception of reality of international and EU law is based on the ideas of resolving past historical fears. At these points, conflict between reality-responsive politics and the supranational legal and institutional world based on fears of the past began. However, the conflict is still at an early stage and international and EU institutions continue to "keep the nation states in the trap of the past".

\section{The traps of history}

International and EU institutions have become a dense legal and institutional network over the last half a century. This has been created both by the interests of the victorious states of World War II and the "fear complex" of a new global war. Within the dense web woven around and above the nation states, several power centres and structures have been created. 
Apolitical professionalism has created bureaucracies that have become a new supranational elite. The concept of Juristocracy refers to this bureaucracy within EU institutions, which appears as a factor of power, i.e. a kind of oligarchy. In the theory of Juristocracy, the picture of a stable and professional power structure emerges in the apparatus which applies and enforces the law. It is a more stable and efficient power structure than the seeking and fluctuation of political compromise of member state governments, i.e. the EU Council. This new power structure is ex officio operated and maintained by the Juristocracy of the EU's legal institutions. It regards this as a vocational interest and even a value. To the extent EU member state policy is weakened, its bureaucratic-legal power structure is strengthened. Thus, a power conflict between the institutional power structure of the Member States and the EU has been increasing. The bureaucratic power structure, by its very nature, is not democratic, as opposed to the weakening but democratically legitimised national policies. At this point, the concept of Juristocracy argues for the tyranny (oligarchy) of an elite and also its effectiveness over the Member States. The "power capacity" of the national politics operating on a democratic basis is fragile since the voters' confidence has to be gained every few years. It seems that political power can be accumulated more effectively by uncontrolled and non-transparent "bureaucratic networks" than national governments.

Paradoxically, the historical trap has been set by nation states, themselves. They have established supranational institutions that have become power factors, speaking legal language while fighting a political battle with the Member States. International and EU institutions, like all cultural entities, over time manifest their own ambitions of power, striving to absolutise their own set of values through legal principles or case law. Ordinary courts, constitutional courts, universities, international organisations, trade unions, academies and human rights institutions are all important political and social institutions in a democracy. However, they still operate with a (socio-evolutionary) code of power, that is, seeking influence and power for their own "cultural survival”. Projecting this approach to the elites of groups, bureaucracy, the legal apparatuses, judicial elites and a variety of institutional elites, exemplifies the fact that they are in a power-evolution struggle with other institutions, even with the governments of nation states. The existence of European Juristocracy is not a revelation in this respect, at least not in an socio-evolutionist approach.

It should be noted that in the meantime, nation states are also struggling with their own crisis of democracy, which also have factors beyond the issues discussed here. ${ }^{7}$ The politics and governments of nation states are struggling in this tightly woven institutional and power network, and are caught in "the traps of history". The opportunities for sovereign and legitimate national governments to resist and become free are limited. However, the European integration "project" seems to disintegrate and fulfil Osvald Spengler's prediction about Western civilisation. ${ }^{8}$ European integration as a political process coming to a halt is an important factor in the coercion of changing the era and of new political theories. There have always been crises in the history of the EU, but today there is more to it than that: the process of deepening and expanding integration has come to a standstill. Not only does the federalist movement seem to fail, but the purpose and

Norbert Kis, 'Anti-Politics, Populism and Political Psychology', Comparative Politics 9, no 2 (2018), 83-93. Osvald Spengler, The Decline of the West (Alfred A Knopf, 2nd ptg edition, 1926). 
meaning of European integration have become questionable. Some believe that the EJC and the federalist Juristocracy have convinced Europe that the EU code of operation is the "ever closer union", i.e. the need for the dynamics of increasing integration and the strengthening of the supranational level. ${ }^{9}$ The ECJ cases of Van Gend en Loos and Costa v. Enel (1962 and 1964) broke with the nature of international law regarding Community law, declaring its direct effect and primacy over the legal systems of the Member States. If integration slows down or stops, there will be an operational crisis and, in the long run, the EU institutional system will become pointless and unsustainable. By contrast, the original purpose of establishing the EU (EC) was to build a community necessary for economic cooperation, and now we should return to this.

The EU Commission and its allied ECJ pursue federalist policies, whereas "policy making" at the strategic level is not their duty. However, it would be contrary to their own bureaucratic nature and the power "instinct" of the institutions if they did not operate "expansively". The real question is whether the Member States can give the EU a new meaningful common purpose, that is, a different "code" of operation than the one created and maintained by the "myths" of federal integration provided by ECJ and EU Juristocracy. Until such a political decision is taken, it would be an illusion to expect the EU institutions to operate in ways that are not federalist and do not serve the policy making that deepens integration. A new political direction must be set at the level of the Council of heads of state or government of the Member States and the Treaty.

To sum up, the institutional system of EU integration has moved away from the democratic central point as an "expanding universe of power”. This central point should be the basis for all politics: popular will. In the long term, the possibility of democratic control determines the viability of a political institution, in the short term, however, not necessarily. This is why the criticised EU institutions were able to extend beyond popular will. This might have been a necessary "evolutionary" process, but it is still the basic element of the dramatic conflict between the nation states and EU institutions. The theory of Juristocracy also argues power ambitions for the survival of the weakening liberal political order in the operation of these institutions. By identifying the interests of political groups, we are once again in the middle of a power struggle.

\section{Conclusions}

One of the motives of Juristocracy theories is that the power struggle must be fought according to the nature and means of politics. Juristocracy fights a political power struggle with legal means. The concept of Juristocracy claims "unfairness” by putting legal arguments which hide purely political reasons. The methods and tools of Juristocracy seem to be the "normal operation" of institutions and their apparatuses under examination. Courts decide disputes, juristocratic academics educate and publish, and NGOs engage in human rights protection. The concept of Juristocracy qualifies these practices that transform political goals into abusive legal arguments. All this can be logical, because if

9 János Gyurgyák, Európa alkonya [The Twilight of Europe] (Budapest: Osiris, 2018). 
an opponent in a battle has swords and pistols lawfully, he will use them in the battle. In the meantime, he will disguise himself and use other stratagems. This is the case with the toolkit of Juristocracy, should it be court judgments, case law, preliminary rulings, a "pilot judgment" proceeding, legal education and publications or human right submissions. The "populist card" is also part of the struggle. The transparency of supranational institutions is less accountable than governments. The explanation and effect of this is the lack of democratic electorate control. Social confidence in the institution of the EU shows a declining tendency according to data of Standard Eurobarometer 2015-2018. These institutions (EC, ECJ, ECHR, NGOs) do not receive social confirmation as opposed to the governments operating with electoral legitimacy. These institutions are irritated by the democratic empowerment of the governments and by their reference to popular will. The accusation of the governments' populism easily emerges, and the governments are not only labelled by liberal political groups and media but are also retaliated against as a legal investigation in a legal veil. An example of this is the initiation of the EU Commission's "Rule of Law Framework". The main weapon of Juristocracy is the "legal rhetoric" of political debates. The method is explained in the concept of the common language of European Constitutional Law. According to this, both state and political doctrine should be translated into legal dogmatics, i.e. constitutional law. ${ }^{10}$ Judicial or case law applies this tool at the highest level. However, the ECJ and ECHR judges are often unable to become independent because they are "hostages” (Béla Pokol) to the hierarchical legal apparatus that dominates the judgments through the techniques of case law restrictions and the applied legal language. Pokol also considers the French language accepted as the only working language of the ECJ as a "trap”, which narrows the Member States' actual room for manoeuvre in the language of legal disputes.

The crisis of the legitimacy of institutional control over elected political power is a historical archetype. The modern form of the archetype is based on Rousseau's theory of popular sovereignty. International judicial and supranational institutions have an $a b$ ovo legitimacy deficit. However, this can be temporarily replaced by a system of values and trust provided to them by nation states. However, if the institutions show powerpolitical attributes, this fragile "legitimacy" may cease to exist. This is where the theory of Juristocracy evolves, which basically criticises the control of certain legal institutions, institutions of law - especially judicial power over the government (executive) power, its extent and quality. The theory, however, must not go beyond the classical political-ethical principle: the exercise of power must be forced by the dismantling of sovereignty and the concentration of power, so that it is truly subordinated to the judgment on its own right. Political governance must be controlled by checks and balances of power. It is risky to question the authority of the legal principles created by the development of the idea of democracy and the rule of law and their interpretation and enforcement by independent judicial forums. This is a historical risk of the debate between the emerging post-liberal ideology and the theory of Juristocracy, which may be another historical trap.

10 András Jakab, Az európai alkotmányjog nyelve [The Language of the European Constitutional Law] (Budapest: NKE Szolgáltató Kft., 2016). 
One of the hypotheses of this paper is that the theory of Juristocracy is a historical necessity. This theory necessarily emerges in post-liberal ideology, as generally the problem of the power of the supranational judicial forums cannot be avoided. The basic motif of the post-liberal era is the historical force of strengthening the sovereignty and capacity of state governance. ${ }^{11}$ This implies conflicts, as a significant part of the power has been taken by international and European judicial forums over the past half-a-century. As an additional risk, it is important to realise that the functioning of international and European trade is also jeopardised by the challenge and dismantling of the authority of supranational institutions. Yet the struggle for sovereignty is moving in that direction. The expansion of nation states' room for manoeuvre will be a long, perhaps decades-long process. However, we should not just think of a black-or-white, win-lose outcome. A new deal is needed on the relations between states and supranational institutions, within the EU, too. A new paradigm should be elaborated that envisages a horizontal order for a closer community of states rather than the hierarchical order of the (neo) liberal era. History will reshape the hierarchical order of "above" (international and European institutions) and of "below" (nations). This will also take time on a historical scale, as the path to power rearrangement is being lead on a political battlefield. The power structures that are able to level other power groups gain historical opportunity. ${ }^{12}$ Nation states have historical and socio-psychological foundations, so they have the right to their own historical survival. Not only nation state sovereignty, but our existence as a nation state will be at stake.

\section{References}

Boyd, Robert and Peter J Richerson, Culture and the Evolutionary Process. Chicago: University of Chicago Press, 1985.

Cohen, Mathilde, 'Judges or Hostages? Sitting at the Court of Justice of the European Union and the European Court of Human Rights', in EU Law Stories. Contextual and Critical Histories of European Jurisprudence, ed. by Fernanda Nicola and Bill Davies. Washington, D.C.: Cambridge University Press, 2017, 58-80. Online: https://doi. org/10.1017/9781316340479.004

Csányi, Vilmos, Az evolúció általános elmélete [The General Theory of Evolution]. Budapest: Akadémiai Kiadó, 1979.

Gyurgyák, János, Európa alkonya [The Twilight of Europe]. Budapest: Osiris, 2018.

Harari, Yuval N, Homo Deus. Harper Collins, 2018. Online: https://doi. org/10.17104/9783406704024

Hirschl, Ran, Towards Juristocracy. The Origins and Consequences of the New Constitutionalism. Boston: Harvard University Press, 2004.

11 István Stumpf, Erős állam, alkotmányos korlátok [Strong State, Constitutional Constraints] (Budapest: Századvég, 2014).

12 Norbert Kis, 'The power of virtuality as a challenge for governments: A post-state dystopia', in Central and Eastern European eDem and eGov, ed. by András Nemeslaki, Alexander Prosser, Dona Scola and Tamás Szádeczky (Wien: Austrian Computer Society, 2019), 107-114. 
Jakab, András, Az európai alkotmányjog nyelve [The Language of the European Constitutional Law]. Budapest: NKE Szolgáltató Kft., 2016.

Kingsbury, Benedict, 'Foreword: Is the Proliferation of International Courts and Tribunals a Systemic Problem?’ N. Y. U. Journal of International Law and Politics 31 (1999).

Kis, Norbert, 'Anti-Politics, Populism and Political Psychology'. Comparative Politics 9, no 2 (2018), 83-93.

Kis, Norbert, 'The power of virtuality as a challenge for governments: A post-state dystopia', in Central and Eastern European eDem and eGov, ed. by András Nemeslaki, Alexander Prosser, Dona Scola and Tamás Szádeczky. Wien: Austrian Computer Society, 2019, 107-114.

Pokol, Béla, Európai jurisztokrácia [European Juristocracy]. Budapest: Dialóg Campus Kiadó, 2019.

Somek, Alexander, 'Administration without Sovereignty', in The Twilight of Constitutionalism?, ed. by Petra Dobner and Martin Loughlin. Oxford: Oxford University Press, 2010. Online: https://doi.org/10.1093/acprof:oso/9780199585007.001.0001

Spengler, Osvald, The Decline of the West. Alfred A Knopf, $2^{\text {nd }}$ ptg edition, 1926.

Stumpf, István, Erős állam, alkotmányos korlátok [Strong State, Constitutional Constraints]. Budapest: Századvég, 2014.

Teitel, Ruti and Robert Howse, 'Cross-Judging: Tribunalization in a Fragmented but Interconnected Global Order’. N. Y. U. Journal of International Law and Politics 41 (2009), 292-294.

Zito, Anthony Z, 'Epistemic Communities, European Union Governance and the Public Voice'. Science and Public Policy 28, no 6 (2001), 465-476. Online: https://doi. org/10.3152/147154301781781183 